\title{
Apakah yang Cape Town Perlu Katakan pada [Kaum Injili di] Indonesia? Suatu Tinjauan dan Refleksi terhadap Komitmen Cape Town dan Implikasinya pada Kaum Injili di Indonesia
}

\author{
Adrianus Yosia* \\ *Penulis menyelesaikan studi di ITB dan melanjutkan pendidikan pascasarjana di STT SAAT. Penulis tertarik \\ dengan isu-isu seputar teologi publik, misiologi dan teologi kontekstual. Saat ini penulis sedang melayani di \\ GKKK Ambon. \\ Email: tartarus.in.my.dream@gmail.com
}

\begin{abstract}
Abstrak: Dokumen Komitmen Cape Town merupakan salah satu dokumen yang sangat penting di dalam sejarah kaum injili. Namun, penulis melihat bahwa dokumen ini jarang sekali dibahas di dalam kancah perteologian di Indonesia. Dengan demikian, artikel ini akan membahas butirbutir pemikiran dari Komitmen Cape Town dan mengontekskannya ke dalam dua konteks sosial di Indonesia, yaitu kondisi multikultur dan multikulturalisme dan juga kemiskinan dan ketimpangan. Hasil akhir dari pembahasan ini adalah sepuluh buah saran (dalam bentuk indikatif dan imperatif) yang dapat menjadi acuan bagi kaum injili di Indonesia.
\end{abstract}

Kata-kata kunci: Komitmen Cape Town, Kemiskinan, Multikulturalisme, Multikultur, Ketimpangan, Kemiskinan, Imperatif dan indikatif, Injili

Abstract: The Cape Town Commitment is one of the important documents pertaining to the history of evangelicals today. Even though this document is important rarely is it discussed in the Indonesia context. Thus, this article will discuss the Cape Town Commitment within two social contexts in Indonesia; multiculturalism and the multicultural condition and with respect to the evident poverty and economic gap. This study results in ten specific suggestions (in both the indicative and the imperative) that can function as guidelines for evangelicals in the Indonesia context.

Keywords: The Cape Town Commitment, Poverty, Multiculturalism, Multicultural, Poverty, Economic Gap, Imperative and indicative, Evangelical 


\section{Pendahuluan}

Dokumen Komitmen Cape Town (The Cape Town Commitment) merupakan salah satu dokumen yang penting bagi kaum injili. ${ }^{1}$ Hal ini pun dikuatkan oleh pengakuan dari Harold Netland, seorang pakar teologi agama-agama injili. $^{2}$ David Neff, kepala penyunting dari majalah Christianity Today pun mengakui betapa pentingnya dokumen ini. ${ }^{3}$ Pentingnya dokumen ini pun tentunya disetujui oleh WEA (World Evangelical Alliance) di dalam ketergabungan organisasi ini dalam gerakan Lausanne (The Lausanne Movement) pada tahun 2014. ${ }^{4}$ Namun, penulis melihat bahwa kaum injili di Indonesia masih belum banyak menggarap butir-butir pemikiran dari dokumen yang sangat penting ini.

Dengan demikian, inilah tujuan utama dari tulisan ini, yaitu mencoba untuk mendedahkan pemahaman-pemahaman teologis yang termaktub di dalam dokumen ini dan

${ }^{1}$ Komitmen Cape Town akan penulis singkat menjadi TCTC pada artikel ini. Pertanyaannya, siapakah yang dimaksud dengan kaum injili di Indonesia? Mengingat istilah injili sendiri sangatlah problematis (lih. Jan S. Aritonang, Berbagai Aliran di Dalam dan di Sekitar Gereja, 5th ed. [Jakarta: Gunung Mulia, 2010], 227-228); Mark A. Noll, "Ecumenical Realities and Evangelical Theology," dalam Renewing the Evangelical Mission, ed. Richard Lints (Grand Rapids: Eerdmans, 2013), 52-53. Namun, penulis akan sepakat dengan pandangan dari Yakub B. Susabda bahwa kaum injili "menyerahkan hidupnya pada Kristus dan 'menjawab panggilan Allah' dalam memberitakan Injil berita anugerah keselamatan" (lih. Yakub B. Susabda, Kaum Injili, 2nd ed. [Malang: Gandum Mas, 1997], 12-13). Untuk penjelasan yang senada dengan Susabda, lih. J. I. Packer dan Thomas C. Oden, Satu Iman, ed. Yessy dan Lautan Asima Siregar (Jakarta: Gunung Mulia, 2011), 9; lih. juga Alister McGrath, Evangelicalism and The Future of Christianity (Downers Grove: Inter Varsity, 1995), 55-56. Bagi penulis, definisi kaum injili dari Susabda, Packer dan juga McGrath ini sudah cukup menyatakan golongan yang ingin penulis sasar pada artikel ini.

${ }^{2}$ Harold Netland dan Gerald R. McDermott, $A$ Trinitarian Theology of Religions: An Evangelical Proposal (Oxford: Oxford University Press, 2014), 5.

${ }^{3}$ David Neff, "Love Language," Christianity Today, Desember 2010, 36.

4"WEA Joins Lausanne Movement in Celebrating 40th Anniversary of Lausanne Congress and Lausanne Covenant," http://www.worldea.org/news/4383/wea-joinslausanne-movement-in-celebrating-40th-anniversary-oflausanne-congress-and-lausanne-covenant (diakses 30 Agustus 2016). mengontekskannya di dalam situasi sosial di Indonesia secara khusus di dalam konteks multikultur, multikulturalisme dan kemiskinan juga kesenjangan. Atas tujuan ini, penulis akan membagi tulisan ini ke dalam tiga bagian besar. Pada bagian yang pertama, penulis akan membuat suatu survei mengenai konteks berteologi di Indonesia. Pada bagian yang kedua, penulis akan membahas sedikit mengenai dokumen TCTC dan juga implikasinya kepada Indonesia di dalam konteks berteologi. Pada bagian ini pula penulis akan mencoba memasukkan beberapa pandangan teolog Indonesia yang berselarasan dengan ide-ide yang sudah dituliskan mengenai topiktopik pembahasan dari Komitmen Cape Town pada catatan kaki. Pada bagian yang terakhir, penulis akan menyimpulkan tulisan ini dan juga memberikan beberapa saran.

\section{Suatu Survei Mengenai Konteks Berteologi di Indonesia}

Berbicara mengenai Indonesia, penulis melihat bahwa minimal ada dua konteks sosial yang dapat menjadi konteks berteologi di Indonesia. Konteks yang pertama adalah kondisi multikultur dan multikulturalisme. Konteks yang kedua adalah kemiskinan. Tentunya, dua konteks ini mempunyai keterhubungan. ${ }^{5}$ Hanya saja, penulis tidak akan membahas keterhubungan mengenai dua konteks ini pada artikel ini mengingat keterbatasan ruang pembahasan.

\section{Kondisi Multikultur dan Multikulturalisme: antara Keseragaman dan Keberagaman}

Kondisi multikultur merupakan bagian yang hakiki dari bangsa Indonesia. ${ }^{6}$ Kondisi multikultur ini pun terekam di dalam hasil sensus

\footnotetext{
${ }^{5}$ Arief Budiman membahas kekerasan yang terjadi antara umat Islam dan Kristen dipicu oleh perbedaan kelas ekonomi (lih. tulisan Budiman dalam Elga Sarapung, Noegroho Agoeng, dan Alfred B. Jogoena, eds., Dialog: Kritik \& Identitas, edisi ketiga [Yogyakarta: Interfidei, 2004]). Tentunya, ide dari Budiman ini sangatlah menarik untuk dikaji, namun penulis tidak akan membahas keterhubungan ini mengingat keterbatasan ruang di dalam artikel ini.

${ }^{6}$ Balitbang PGI, ed., Agama dalam Dialog (Jakarta: Gunung Mulia, 1999), 124-125.
} 
tahun 2010 yang dilakukan oleh Badan Pusat Statistik (BPS). Dari hasil sensus tahun 2010, BPS mencatat bahwa di Indonesia ada 1.340 suku bangsa yang di dalam kesehariannya menggunakan sekitar 2.500 bahasa daerah. ${ }^{7}$ Di dalam laporan yang sama, BPS menyatakan bahwa keragaman suku dan bahasa masih terpelihara sampai saat ini. Perihal ini bersesuaian dengan penelitian dari BPS bahwa sekitar 79,2\% penduduk masih menggunakan bahasa daerahnya masing-masing pada kehidupan sehari-hari. ${ }^{8}$ Dengan demikian, kondisi multikultur memang menjadi bagian yang hakiki dari bangsa Indonesia. Hal yang menarik, kondisi multikultur ini pun diperkaya dengan ragam agama ataupun aliran kepercayaan yang ada di Indonesia. ${ }^{9}$

Di Indonesia, terdapat enam agama mayoritas (Kristen, Katolik, Hindu, Buddha, Islam, Kong $\mathrm{Hu} \mathrm{Cu}$ ) ditambah lagi dengan ragam aliran kepercayaan dari suku-suku yang ada di Indonesia. Namun, penulis melihat bahwa enam agama ini justru menjadi pilarpilar utama dari multikultur ini. Maksudnya, walaupun terdapat keragaman aliran kepercayaan, suku ataupun agama suku di Indonesia, tetap saja enam agama utama ini menjadi identitas utama dari ragam budaya dan ragam agama suku ini. Minimal ada tiga alasan yang mendasari klaim dari penulis.

Pertama, dasar negara Indonesia adalah Pancasila di mana sila pertama berbunyi demi-

${ }^{7}$ BPS, Kewarganegaraan, Suku Bangsa, Agama, dan Bahasa Sehari-hari Penduduk Indonesia (t. k.: BPS, 2010), 5-6, http://www.bps.go.id/website/pdf_publikasi/watermark\%20_Kewarganegaraan,\%20Suku\%20Bangsa,\%20 Agama\%20dan\%20Bahasa 281211.pdf (diakses 25 Oktober 2015).

${ }^{8}$ BPS, Kewarganegaraan, Suku Bangsa, Agama, dan Bahasa Sehari-hari Penduduk Indonesia, 5-6.

${ }^{9}$ Penulis sadar bahwa di dalam agama pun terdapat konsep budaya di dalamnya. Tidak hanya itu, di dalam budaya pun, secara khusus di Indonesia, agama mempunyai andil di dalam pembentukan budaya (lih. Kevin J. Vanhoozer, First Theology: God, Scripture, and Hermeneutics [Downer Grove: InterVarsity, 2002], 325-326). kian: "Ketuhanan yang Maha Esa."10 Lewat kehadiran sila yang pertama ini sebagai dasar negara, dapat disimpulkan bahwa agama utama ini mendahului kesukuan. Karena itu, agama tidak dapat dilepaskan dari kehidupan bernegara Indonesia. Alasan yang kedua berhubungan dengan sisi hukum dari kewarganegaraan di Indonesia. Beberapa undangundang, seperti undang-undang perkawinan ataupun kependudukan, mengharuskan adanya agama sebagai prasyarat pernikahan ataupun bagian dari identitas. ${ }^{11}$ Karena itu, kehidupan bermasyarakat di Indonesia pastilah tidak terlepas dari enam agama mayoritas yang ada di Indonesia. Terakhir, di Indonesia identitas keagamaan dan juga kesukuan tidak dapat dilepaskan dari masyarakat Indonesia. Terlebih lagi, dengan eratnya identitas komunal di dalam kesukuan di Indonesia (kinship). ${ }^{12}$ Mengingat dua alasan sebelumnya, agama yang lebih mengikat kesukuan adalah enam agama utama sebagai bagian dari identitas komunal. Dengan demikian, bagi penulis, tiga alasan ini memberikan dua sisi keberagaman dan juga keseragaman.

Pada satu sisi, keragaman di dalam masyarakat Indonesia dapat dibagi ke dalam enam kelompok berdasarkan agama utama.

\footnotetext{
${ }^{10}$ Ateisme nampaknya masih sulit untuk dijadikan salah satu landasan ber-"agama" di Indonesia, mengingat sila pertama pada Pancasila menyatakan: "Ketuhanan Yang Maha Esa." Tidak hanya itu, butir pertama dari sila yang pertama ini juga menyatakan: "Percaya dan takwa kepada Tuhan Yang Maha Esa sesuai agama dan kepercayaan masing-masing menurut dasar kemanusiaan yang adil dan beradab." (t.p., "Butir-Butir Pancasila," 1, http:// bphn.go.id/data/documents/butir-butir_pancasila_1.doc [diakses 1 Maret 2016]).

${ }^{11}$ Pernikahan pun hanya dapat dilakukan apabila kedua pasangan ini telah beragama (t.p., "UndangUndang Republik Indonesia No. 1 Tahun 1974 Tentang Perkawinan," 2.1 http://www.kemenag.go.id/file/dokumen/ UUPerkawinan.pdf [diakses 14 Maret 2016]). Apabila ada seseorang yang tidak beragama dapat mengosongkan kolom bagian agama di dalam pengisian KTP. Namun, di dalam sensus penduduk tahun 2010, tidak tercatat adanya kolom agama yang dikosongkan di dalam pendataannya. Dengan demikian, agama masih menjadi identitas yang penting di Indonesia.

${ }^{12}$ Clarke E. Cunningham, "Indonesia," dalam Countries and Their Cultures, ed. Carol R. Ember dan Melvin Ember, (New York: Macmillan Reference USA, 2001), Gale Virtual Reference Library.
} 
Walaupun gambaran ini seakan-akan kasar dan tidak memperhatikan detail yang ada di dalam masyarakat, pembagian ini cukup untuk membagi masyarakat Indonesia ke enam kelompok saja. Pada sisi yang lain, di dalam individu ataupun juga komunitas di Indonesia yang tersekat di dalam enam gologan besar ini, terdapat juga kompleksitas dan juga keberagaman. Karena itu, kata multikulturalisme ini sangatlah tepat di dalam menggambarkan kondisi individu ataupun komunitas di Indonesia dengan enam agama besar ini sebagai pilarnya.

Kamus Besar Bahasa Indonesia (KBBI) mendefinisikan multikulturalisme sebagai gejala pada seseorang atau suatu masyarakat yang ditandai oleh kebiasaan menggunakan lebih dari satu kebudayaan. Dengan demikian, kondisi multikulturalisme ini termanifestasikan dalam keberagaman di dalam ragam budaya di Indonesia, misalkan saja komunitas Batak-Kristen, Batak-Islam, Tionghoa-Kristen, Tionghoa-Kristen, dsb. Bahkan wujud multikulturalisme ini pun dapat terlihat di dalam kota atau tempat dia tinggal. Misalkan saja, Tionghoa-Kristen-Ambon akan sangat berbeda dengan Tionghoa-Kristen-Bandung. Dengan demikian, multikulturalisme mendampingi keadaan multikultur yang ada di Indonesia. Multikulturalisme ini pun mencakup sinkretisme agama suku di dalam kehidupan berbangsa Indonesia.

Sekitar empat puluh tahun yang lalu, Mochtar Lubis menyatakan demikian di dalam ceramah yang diadakan di Taman Ismail Marzuki, Jakarta:

Kaki kita sebelah masih terpancang di budaya animisme kita, dan yang sebelah lagi terpancang di zaman modern sekarang ini dengan segala nilai-nilainya yang berubah amat pesat, dan kita selalu ketinggalan mengikutnya sedikitnya 20 tahun. Dan antara kedua kaki kita berlapis-lapislah segala rupa pengaruh baik yang lama maupun yang baru, dan demikian silih berganti. Salah satu kelemahan kita, menurut saya, ialah kita tidak berdaya melakukan pilihan, semuanya kita terima, dan kita biarkan hidup bersama tanpa mengganggu jiwa kita. Pergi meminta ke pohon keramat atau pada Sang Hyang Sri tidak mengganggu perasaan kita sebagai orang Islam atau orang Nasrani. Orang yang beragama juga tidak merasa janggal ataupun canggung menjadi murid seorang guru atau dukun yang mencari tanda-tanda ngalamat di bintang, atau pada air bening dalam gelas, atau dalam mimpi maupun firasat. ${ }^{13}$

Dengan demikian, multikulturalisme di Indonesia mencakup kompleksitas suku, agama, ataupun kepercayaan yang di dalam kehidupan komunitas ataupun individu di Indonesia. ${ }^{14}$ Jadi, bisa dikatakan hubungan antara multikultur dan multikulturalisme ini merupakan dua hal yang tidak dapat dipisahkan. Di dalam situasi multikultur yang dapat disekat dalam enam agama (keseragaman), terdapat juga kondisi multikulturalisme (keberagaman).

\footnotetext{
${ }^{13}$ Manusia Indonesia (Jakarta: Idayu, 1974), 14; penekanan oleh penulis. Lihat juga beberapa karya yang berhubungan dengan sosiologi dalam Roy Ellen, "Anger, Anxiety, and Sorcery: An Analysis of Some Nuaulu Case Material from Seram, Eastern Indonesia," dalam Understanding Witchcraft and Sorcery in Southeast Asia, ed. C. W. Watson dan R. F. Ellen (Hawaii: University of Hawaii Press, 1993), 81-97; John R. Bowen, "Return to Sender: A Muslim Discourse of Sorcery dalam a Relatively Egalitarian Society, the Gayo of Northern Sumatra," dalam Understanding Witchcraft and Sorcery in Southeast Asia, ed. C. W. Watson dan R. F. Ellen (Hawaii: University of Hawaii Press, 1993), 179-190; Ronny Nitibaskara, "Observation on the Practice of Sorcery in Java," dalam Understanding Witchcraft and Sorcery in Southeast Asia, ed. C. W. Watson dan R. F. Ellen (Hawaii: University of Hawaii Press, 1993), 123-133; Gregory Forth, "Social and Symbolic Aspect of the Witch among the Nage of Eastern Indonesia," dalam Understanding Witchcraft and Sorcery in Southeast Asia, ed. C. W. Watson dan R. F. Ellen (Hawaii: University of Hawaii Press, 1993), 99-122. Penulis berterima kasih kepada Bapak Richard J. Konieczny yang sudah memperkenalkan pendekatan sosiologis pada penulis lewat artikel-artikel yang diberikan pada mata kuliah Demonologi.
}

${ }^{14}$ Anne Schiller, "An 'Old' Religion in 'New Order' Indonesia: Notes on Ethnicity and Religious Affiliation," Sociology of Religion 57, no. 4 (Winter 1996): 409-417. Di dalam artikel ini, Schiller menjelaskan mengenai orangorang Dayak yang masih memegang adat dengan erat namun juga memegang erat keagamaannya. Walaupun penelitian Schiller masih terfokus pada suku Dayak di Kalimantan, penulis melihat bahwa sinkretisme adat dan agama pun merupakan hal yang lumrah di Indonesia. 
Dengan demikian, bagaimanakah seorang injili di Indonesia dapat menghidupi perannya di dalam situasi yang multikultur ini? Bagaimanakah seorang injili di Indonesia dapat melihat peranannya di bangsa ini? Tentunya, rekomendasi mengenai apa yang dapat dilakukan oleh seorang injili di Indonesia akan penulis coba jawab pada bagian berikutnya. Hanya saja, terdapat konteks sosial lain yang mengiringi kondisi multikultur dan juga multikulturalisme di Indonesia yaitu, kemiskinan.

\section{Kemiskinan dan Ketimpangan Sosial ${ }^{15}$}

Penulis melihat bahwa salah satu problema laten di Indonesia adalah kemiskinan. Tentunya indikasi mengenai kemiskinan hanya dapat dilacak dari data-data yang diunggah oleh Badan Pusat Statistik pada situs resminya. BPS menyatakan bahwa jumlah penduduk miskin per Maret 2016 adalah 10,86\% atau setara dengan jumlah 28,06 juta orang, turun sekitar $0,50 \%$ dari data kemiskinan pada bulan September 2015. ${ }^{16}$ Tentunya dengan melihat jumlah orang-orang yang miskin sesuai data BPS, seakan-akan tidak ada masalah yang "serius" mengenai kemiskinan. Padahal, seperti yang sudah penulis utarakan, kemiskinan merupakan suatu bahaya laten di Indonesia.

Bahaya laten ini dapat terjadi karena tiga alasan. Pertama, konsep kemiskinan yang diusung oleh BPS. Perhitungan jumlah orang yang miskin ala BPS dilakukan dengan mencari nilai dari Garis Kemiskinan (GK). ${ }^{17}$ Pada situs resminya, BPS mendefinisikan kemiskinan dan juga penduduk miskin demikian:

\footnotetext{
${ }^{15}$ Sebagian besar materi pembahasan dari subjudul ini sudah penulis tulis pada artikel "Merajut Harapan dari Kenangan," dalam Tulis Pikir ITB 2006. Buku ini merupakan buku kenang-kenangan dari acara reuni pasca 10 tahun kelulusan dari alumnus ITB 2006. Buku ini juga merupakan kompilasi dari esai-esai para alumnus ITB 2006. Materi ini pun revisi dan ekspansi ide dari salah satu artikel yang pernah penulis tulis pada jurnal mahasiswa SAAT (lih. Adrianus Yosia, "Let the Indonesian Hear His Voice," Consilium 13 [July 2015]: 117-131).

${ }^{16} \mathrm{https} / / / w w w . b p s . g o . i d / B r s / v i e w / i d / 1229$ (diakses 29 Juli 2016).

${ }^{17}$ Untuk perhitungan Garis Kemiskinan (GK), lih. BPS, "Perhitungan Garis Kemiskinan," https://www.bps. go.id/Subjek/view/id/23 (diakses 29 Juli 2016).
}

[K] emiskinan dipandang sebagai ketidakmampuan dari sisi ekonomi untuk memenuhi kebutuhan dasar makanan dan bukan makanan yang diukur dari sisi pengeluaran. Jadi Penduduk Miskin adalah penduduk yang memiliki rata-rata pengeluaran perkapita perbulan dibawah garis kemiskinan. ${ }^{18}$

Lewat kutipan di atas, logika yang digunakan oleh BPS dalam perhitungan adalah apabila seorang penduduk di Indonesia mempunyai penghasilan lebih besar dari GK, maka dia dapat disebut tidak miskin. Sebaliknya, apabila penduduk itu mempunyai penghasilan di bawah GK, maka dia dikatakan miskin. Namun, di sinilah letak problemanya.

Di dalam Laporan Bulanan Data Sosial Ekonomi yang diterbitkan oleh BPS pada Juli 2016, tercatat bahwa nilai Garis Kemiskinan per September 2015 adalah Rp. 344.809,-. ${ }^{19}$ Dengan demikian, seorang penduduk Indonesia dapat dikatakan miskin apabila mempunyai penghasilan per bulan di bawah jumlah GK tersebut. ${ }^{20}$ Misalkan saja, apabila seorang penjual nasi goreng yang hanya mendapatkan penghasilan Rp. 500.000,- per bulan masih dapat dikatakan tidak miskin. Dengan demikian, sang tukang nasi goreng masih dianggap tidak miskin, walaupun dia tidak dapat menyekolahkan anaknya ataupun memperoleh akses kesehatan. Lewat contoh kasus ini, terdapat problema yang kedua, yaitu perhitungan nilai GK itu sendiri.

Kedua, problema perhitungan nilai (GK). Dari tokoh Kristen sendiri, A. A. Yewangoe pernah mengkritik perhitungan garis kemis-

\footnotetext{
${ }^{18}$ Ibid.

${ }^{19}$ BPS, Laporan Bulanan Data Statistik Agustus 2016, ed. Subdirektorat Publikasi dan Kompilasi Statistik (t. k.: BPS, 2016), https://www.bps.go.id/website/pdf_publikasi/ Laporan-Bulanan-Data-Sosial-Ekonomi-Agustus-2016. pdf (diakses 30 Agustus 2016).

${ }^{20}$ Demikian ujaran di situs resmi BPS, penduduk miskin adalah penduduk yang memiliki rata-rata pengeluaran per kapita per bulan di bawah garis kemiskinan (lih. BPS, "Perhitungan Garis Kemiskinan").
} 
kinan pada tahun $1990 .{ }^{21}$ Yewangoe mengkritik perhitungan garis GK yang belum menunjukkan problema kemiskinan yang sebenarnya. Namun, penulis melihat, kritik Yewangoe belum menyentuh isu perhitungan GK. Yewangoe hanya mengkritik masalah ketidakpedulian gereja di Indonesia terhadap isu kemiskinan. Kritik yang lebih konkret diutarakan oleh Carunia Mulya Firdausy, seorang guru besar ekonomi dari Universitas Tarumanegara dan juga peneliti senior LIPI. Kritik dari Firdausy diutarakan pada harian Kompas pada tahun 2014.

Firdausy menyatakan ada lima alasan sederhana mengapa perhitungan GK perlu direvisi. $^{22}$ Namun, penulis hanya akan membahas dua dari lima kritik yang diutarakan oleh Firdausy. Pertama, bagi Firdausy, perhitungan GK masih terlalu berfokus kepada faktor pangan dan beberapa faktor nirpangan. Akibatnya, terdapat kasus orang miskin yang tidak miskin seperti contoh yang sudah penulis utarakan di atas. Kedua, pemilihan faktor nirpangan yang masih sewenang-wenang di dalam perhitungan GK. Dengan demikian, tinggi ataupun rendahnya nilai GK masih belum mencerminkan keadaan kemiskinan yang sebenarnya. Karena itu, di dalam artikel yang berikutnya, Firdausy melanjutkan usulannya agar pemerintah dapat menaikkan GK. ${ }^{23}$ Dengan demikian, seharusnya ada orang-orang miskin yang lebih banyak jumlahnya dibandingkan data statistik dari BPS.

Problema ini pun diendus oleh Bank Dunia (World Bank). Di dalam salah satu artikel pada halaman situs Bank Dunia, terpampanglah suatu bagian tulisan yang menyatakan demikian:

${ }^{21}$ A. A. Yewangoe, "Keprihatinan dan Harapan Gereja terhadap Masalah Kemiskinan di Indonesia," dalam Gerakan Oikumene: Tegar Mekar di Bumi Pancasila, edisi keempat (Jakarta: Gunung Mulia, 2012), 73. Cetakan pertama dari buku ini dirilis pada tahun 1990.

22“"Revisi Atas Garis Kemiskinan,” Kompas, 11 April 2014, 11.

23“Garis Kemiskinan Perlu Dinaikkan," Kompas, 17 Oktober 2014, http://www.dikti.go.id/garis-kemiskinanperlu-dinaikkan/ (diakses 17 April 2016).
Pertumbuhan ekonomi Indonesia yang kuat telah membantu menurunkan kemiskinan, tetapi tingkat penurunan melambat. Pulihnya pertumbuhan ekonomi pasca krisis finansial Asia pada tahun 19971998 telah membawa pergeseran tenaga kerja dari sektor pertanian ke jasa, serta terciptanya lapangan kerja di kota-kota. Tren ini telah berkontribusi pada berkurangnya kemiskinan dari $24 \%$ pada 1999 menjadi $11,4 \%$ pada awal 2013. Namun, tingkat penurunan kemiskinan mulai melambat. Pada tahun 2012 dan 2013, kemiskinan turun hanya sebesar $0,5 \%$ tiap tahun - terkecil dalam dekade terakhir. Banyak penduduk hidup sedikit di atas garis kemiskinan dan rentan jatuh miskin. Banyak penduduk Indonesia yang berhasil keluar dari kemiskinan masih hidup sedikit di atas garis kemiskinan. Pada tahun 2013, sekitar 28 juta penduduk hidup di bawah Rp 293.000,- per bulan. Selain itu, 68 juta penduduk hidup sedikit di atas angka tersebut. Kejadian kecil bisa dengan mudah membuat mereka jatuh miskin, dan memang banyak keluarga keluar-masuk dari perangkap kemiskinan. ${ }^{24}$

Tentunya, dengan melihat data penduduk miskin dan juga GK yang tidak terlalu jauh pada saat ini, dapat dikatakan bahwa problema fenomena penduduk miskin yang berada di garis kemiskinan ini masih ada. ${ }^{25}$ Dengan demikian, apabila pandangan dari Bank Dunia ini benar, hampir 100 juta penduduk Indonesia rawan ataupun sudah masuk ke dalam kategori miskin. Dengan kalimat lain, $40 \%$ penduduk Indonesia terancam miskin. ${ }^{26}$ Jumlah ini dapat terus bertahan karena ada problema ketimpangan di Indonesia. Dengan demikian, bahaya laten yang menjadi prob-

\footnotetext{
${ }^{24}$ t.p., "Pengentasan Kemiskinan di Indonesia," http:// www.worldbank.org/in/country/indonesia/brief/reducingextreme-poverty-in-indonesia (diakses 14 September 2015).

${ }^{25}$ Dengan melihat garis kemiskinan pada bulan September, terlihat bahwa nilai GK belum berbeda jauh. Karena itu, penulis melihat bahwa problem ini pun masih relevan sampai saat ini.

${ }^{26}$ Carunia Mulya Firdausy, "Garis Kemiskinan Perlu Dinaikkan.”
} 
lema berikutnya di Indonesia adalah ketimpangan.

Ketiga, problema ketimpangan yang menjadi bagian dari problema kemiskinan di Indonesia. Walaupun perekonomian Indonesia mengalami peningkatan, ketimpangan ekonomi di Indonesia semakin tinggi di dalam beberapa tahun terakhir. Ketimpangan yang kian tajam ini tecermin oleh kenaikan koefisien GINI yang menembus nilai 0,4 pada lima tahun terakhir (mulai dari tahun 20102015). ${ }^{27}$ Harian Kompas pada tahun 2016 pun menyatakan bahwa ketimpangan menjadi ancaman yang nyata bagi bangsa Indonesia ini. ${ }^{28}$ Dengan demikian, ada kesan bahwa peningkatan ekonomi yang kian meninggi hanya dinikmati sebagian kalangan saja di Indonesia.

Salah satu artikel yang terpampang pada situs dari Bank Dunia menyatakan demikian mengenai ketimpangan di Indonesia: "However, growth over the past decade has primarily benefitted the richest $20 \%$ and left behind the remaining $80 \%$ of the population - that is more than 205 million people." 29 Dengan demikian, kesenjangan inilah yang menyebabkan kemiskinan tetap menjadi momok bagi bangsa Indonesia.

Lewat tiga perihal ini, penulis melihat bahwa kemiskinan merupakan suatu momok bagi

\footnotetext{
${ }^{27}$ Koefisien GINI adalah suatu koefisien yang menyatakan ketimpangan pada masyarakat (lih. BPS, "Koefisien GINI,” https://sirusa.bps.go.id/sirusa/index.php/indikator/22 [diakses 20 Mei 2016]). Apabila koefisien GINI bernilai 0 , maka tidak ada ketimpangan. Sedangkan apabila koefisien GINI bernilai 1, artinya ada ketimpangan yang sempurna. Berdasarkan data yang diberikan oleh BPS, koefisien GINI dari tahun 2010 sampai dengan tahun 2013 adalah 0,41. Sedangkan pada bulan September 2015 koefisien GINI bernilai 0,40 (lih. BPS, "Berita Statistik September 2015," https://www.bps.go.id/index.php/brs/1277 [diakses 20 Mei 2016]). 2016, 1 .

28“Kesenjangan Jadi Tantangan Besar," Kompas, 2 Juni

${ }^{29}$ t.p., "Indonesia Rising Divide," http://www.worldbank.org/en/news/feature/2015/12/08/indonesia-risingdivide (diakses 13 Mei 2016); lih. juga t.p., "Indonesia: Rising Inequality Risks Long-Term Growth Slowdown," http://www.worldbank.org/en/news/press-release/2015/12/08/rising-inequality-risks-long-term-growthslowdown untuk video yang baik mengenai penelitian dari Bank Dunia.
}

bangsa Indonesia. Dengan demikian, apakah yang harus dilakukan oleh seorang Kristen injili di Indonesia di dalam menghadapi kemiskinan? Sekali lagi, penulis akan mencoba menjawab problema ini lewat pembahasan dari Komitmen Cape Town pada bagian berikutnya. Namun, sebelum penulis membahas isi dari dokumen ini dan mengontekskannya ke dalam dua problem sosial di atas, penulis akan membahas terlebih dahulu mengenai sejarah dan juga ulasan singkat mengenai dokumen Komitmen Cape Town.

\section{Komitmen Cape Town: Suatu Ulasan Singkat}

Dokumen Komitmen Cape Town merupakan bagian dari suatu gerakan yang bernama Gerakan Lausanne (The Lausanne Movement). ${ }^{30}$ Gerakan Lausanne mempunyai tiga buah konferensi yang sangat besar yang dinamakan Lausanne Congress of World Evangelization (LCWE). Tiga pertemuan ini menghasilkan tiga dokumen yang sangat penting bagi kaum injili. Pada LCWE I, dokumen yang dihasilkan adalah Perjanjian Lausanne (The Lausanne Covenant) sedangkan pada LCWE II, dokumen yang dihasikan adalah Manifesto

\footnotetext{
${ }^{30}$ Gerakan ini dimulai dari pertemuan dari kaum injili pada tahun 1974 di Lausanne, Swiss. Pertemuan ini menghasilkan dokumen yang penting, yaitu Perjanjian Lausanne (The Lausanne Covenant). Setelah itu, memang ada beberapa pertemuan yang penting. Namun, salah satu pertemuan yang monumental dari kaum injili dilakukan di Manila pada tahun 1989. Pertemuan kedua ini menghasilkan Manifesto Manila (The Manila Manifesto). Tiga dokumen penting ini, termasuk Komitmen Cape Town dikompilasikan di dalam satu buku. Lih. J. E. M. Cameron, ed., The Lausanne Legacy (Peabody: Hendrickson, 2016); Untuk sejarah dari gerakan Lausanne sendiri, lih. t.p., "About the Movement," https://www.lausanne.org/ about-the-movement (diakses 31 Agustus 2016). Lih. juga Robert A Hunt, "The History of the Lausanne Movement, 1974-2010," International Bulletin of Missionary Research 35, no. 2 (April 2011): 81-84; Leighton Ford, "Foreword," dalam The Lausanne Legacy, ed. J. E. M. Cameron (Peabody: Hendrickson, 2016), $\mathrm{xx}$-xxii.
} 
Manila (The Manila Manifesto). ${ }^{31} \quad$ Sebagai kelanjutan dari LCWE I dan II, diadakanlah LCWE yang ketiga.

Pada tahun 2010 diadakan LCWE III di Cape Town, Afrika Selatan. Kongres ini dihadiri oleh 4200 pemimpin injili dari 198 negara, belum lagi ratusan ribu partisipan lain yang mengikuti kongres tersebut lewat media online. ${ }^{32}$ C. René Padilla menambahkan, "over 650 GlobalLink sites in 91 countries were connected with the congress, and there were 100,000 unique visits from 185 countries." ${ }^{33}$ Dengan demikian, kongres ini merupakan salah satu pertemuan terbesar di dalam kalangan injili. ${ }^{34}$ Tentunya, pertemuan terbesar ini mempunyai suatu tujuan. Penulis melihat bahwa ada tiga tujuan yang menjadi bagian dari pertemuan ini.

Pertama, tujuan dari pertemuan ini adalah "untuk membawa suatu tantangan yang baru bagi gereja global untuk menyaksikan Yesus Kristus dan segala ajaran-Nya kepada setiap negara, setiap aspek kehidupan dan di dalam dunia ide." 35 Dengan demikian, menyaksikan ajaran Yesus Kristus pun termaktub di dalam

\footnotetext{
${ }^{31}$ Dua dokumen ini dapat diakses secara digital. Perjanjian Lausanne dapat diakses dengan melihat situs t.p., "The Lausanne Covenant," https://www.lausanne.org/ content/covenant/lausanne-covenant (diakses 23 September 2016). Sedangkan Manifesto Manila dapat diakses pada t.p., "The Manila Manifesto," http://www.lausanne. org/content/manifesto/the-manila-manifesto (diakses 8 September 2016). Sejarawan Mark E. Knoll juga menyatakan bahwa dokumen Perjanjian Lausanne (termasuk juga Manifesto Manila dan Komitmen Cape Town) sebagai salah satu hal yang penting bagi kaum injili (lih. Mark A. Noll, Turning Points: Decisive Moments in the History of Christianity, edisi ketiga [Grand Rapids: Baker Academic, 2012], 297-305).

32"The Cape Town Commitment: A Confession of Faith and A Call to Action," International Bulletin of Missionary Research 35, no. 2 (April 2011): 59-80.

33"The Future of the Lausanne Movement," International Bulletin of Missionary Research 35, no. 2 (April 2011): 86.

${ }^{34}$ Sebagaimana diutarakan oleh Doug Birdsall dalam "The Future of the Lausanne Movement," 86.

35"To bring a fresh challenge to the global Church to bear witness to Jesus Christ and all his teaching-in every nation, in every sphere of society, and in the realm of ideas" ("The Cape Town Commitment: A Confession of Faith and A Call to Action," 59; terjemahan oleh penulis).
}

konteks multikulturalisme, multikultur dan kemiskinan. ${ }^{36}$ Kedua, dokumen yang dihasilkan dari kongres ini akan menjadi semacam peta (roadmap) dari gerakan Lausanne selama beberapa tahun ke depan. ${ }^{37}$ Tentunya, dengan dua tujuan ini, terdapat suatu tema besar yang membingkai Komitmen Cape Town. Tema besar yang merangkum tujuan ini adalah mengasihi Tuhan dan mengasihi sesama. $^{38}$ Ketiga, dokumen ini merupakan kelanjutan dari dua dokumen sebelumnya, yaitu Perjanjian Lausanne dan juga Manifesto Manila. ${ }^{39}$ Tiga tujuan ini menjadi semacam kerangka pikir yang membingkai isi dari Komitmen Cape Town. Dengan demikian, penulis akan membahas gambaran kasar mengenai isi dari dokumen Komitmen Cape Town lebih jauh lagi.

Berbicara mengenai Komitmen Cape Town (TCTC), dokumen ini dibagi ke dalam dua bagian besar yang diapit oleh pembukaan (preamble) dan kesimpulan (conclusion). Bagian yang pertama berhubungan dengan pengakuan iman (The Confession of Faith). Bagian yang kedua berhubungan dengan apa yang harus dilakukan (The Call for Action). Dua pembagian ini meniru sistem berpikir dari surat-surat Paulus, yaitu terdapat bagian indikatif dan juga imperatif. ${ }^{40}$ Bagian indikatif terbagi menjadi sepuluh subbagian dengan tema besar kasih kepada Allah dan kasih kepada sesama. Sedangkan pada bagian imperatif, enam subbagian yang mencakup tema-tema penting seperti kebenaran, per-

${ }^{36} \mathrm{Neff}$ menyatakan bahwa aspek ini adalah aspek misional dari teologi injili (lih. David Neff, "Love Language").

${ }^{376}$ The Cape Town Commitment: A Confession of Faith and A Call to Action," 59. Tujuan ini pun termaktub pada bagian pembukaan dari dokumen ini.

${ }^{38}$ Lindsay Brown, "We Have a Gospel to Proclaim," dalam The Lausanne Legacy, ed. J. E. M. Cameron (Peabody: Hendrickson, 2016), 163.

39" The Cape Town Commitment: A Confession of Faith and A Call to Action," 60; Lih. juga analisis dari Schreiter dalam "From the Lausanne Covenant to the Cape Town Commitment: A Theological Assesment," International Bulletin of Missionary Research 35, no. 2 (April 2011): 60.

${ }^{40}$ Robert J. Schreiter, "From the Lausanne Covenant to the Cape Town Commitment: A Theological Assesment," 89; Lindsay Brown, "We Have a Gospel to Proclaim," 163. 
damaian (shalom) dan juga seputar isu praksis. Dengan demikian, penulis akan mencoba untuk merangkumkan poin-poin yang terdapat pada Komitmen Cape Town dan mengaplikasikannya pada kondisi multikultur, multikulturalisme, kemiskinan dan juga ketimpangan di Indonesia.

\section{Komitmen Cape Town dan Implikasinya pada Indonesia}

Penulis akan membahas implikasi dokumen ini di dalam dua subbagian. Pada subbagian yang pertama, penulis akan menfokuskan butir-butir pembahasan ini pada kondisi multikultur dan multikulturalisme, sedangkan pada subbagian yang kedua penulis akan memfokuskan pembahasan pada kondisi kemiskinan dan ketimpangan di Indonesia.

Metode yang penulis pakai untuk membahas bagian ini adalah membagi poin-poin yang diutarakan pada dokumen Komitmen Cape Town ke dalam beberapa indikatif dan juga imperatif. Penulis akan mencoba untuk memfokuskan ide-ide yang ada pada dokumen Cape Town ini ke dalam fokus pembahasan. Mengingat bahwa konsep yang diutarakan pada dokumen ini saling tumpang tindih.

\section{Apa yang Cape Town Perlu Katakan pada Kondisi Multikultur dan Multikulturalisme di Indonesia}

Indikatif yang pertama. Bagian indikatif yang pertama ini berhubungan dengan pandangan seorang injili terhadap budaya. Mengenai budaya yang ada di dunia ciptaan Allah, TCTC I.7.b menyatakan demikian:

We love the world of nations and cultures. 'From one man, God made all nations of humanity, to live on the whole face of the earth.' Ethnic diversity is the gift of God in creation and will be preserved in the new creation, when it will be liberated from our fallen divisions and rivalry. Our love for all peoples reflects God's promise to bless all nations on earth and God's mission to create for himself a people drawn from every tribe, language, nation and people. We must love all that God has chosen to bless, which includes all cultures. . . . Godly love, however, also includes critical discernment, for all cultures show not only positive evidence of the image of God in human lives, but also the negative fingerprints of Satan and $\sin .^{41}$

Lewat pengakuan ini, penulis melihat minimal ada tiga hal yang dapat diaplikasikan ke dalam situasi multikultur di Indonesia. Pertama, lewat pengakuan ini, seorang injili di Indonesia dapat menyadari bahwa terdapat keindahan di dalam multikultur (ragam budaya) yang ada di Indonesia. Di dalam kondisi ragam budaya ini, tidak hanya dosa personal dan komunal yang terdapat di dalam budaya saja yang menjadi sorotan bagi kaum injili. Terdapat pengakuan akan keindahan di dalam budaya yang telah mengalami kejatuhan (fallen). ${ }^{42}$ Sebagai dampaknya, komunitas injili di Indonesia dapat dengan lebih berani lagi untuk menikmati keindahan dari budaya yang ada pada situasi multikultur ini.

Kedua, perbedaan etnik merupakan keniscayaan, bahkan perbedaan ini harus dilestarikan di dalam kehidupan keseharian seorang injili. Tidak hanya itu, multikulturalisme sebagai bagian dari multikultur ini pun menjadi keniscayaan. ${ }^{43}$ Ketiga , misi ilahi dilaksanakan justru di dalam kondisi yang multikultur ini. Karena itu, penulis melihat bahwa tiga perihal ini dapat menjadi dasar bertindak bagi kaum injili di Indonesia di dalam situasi multikul-

\footnotetext{
41" The Cape Town Commitment: A Confession of Faith and A Call to Action," 64.

${ }^{42}$ Robert J. Schreiter, "From the Lausanne Covenant to the Cape Town Commitment: A Theological Assesment," 89-90. Schreiter sendiri mengakui bahwa pengakuan terhadap keindahan dari budaya dan juga kejatuhan (fall) problematis. Namun, hemat penulis, pengakuan ini dapat memberikan suatu ruang bagi kaum injili untuk kembali merumuskan mengenai budaya. Karena itu, bagi penulis, pengakuan ini signifikan peranannya bagi kaum injili.

${ }^{43}$ Seorang injili pun perlu berhati-hati terhadap primordialisme atau fundamentalisme suku yang sewaktu-waktu mengancam cara pandang yang sehat mengenai keindahan dari budaya lain (lih. "The Cape Town Commitment: A Confession of Faith and A Call to Action," 75). Lihat juga Bidang Marturia, ed., Agama-agama, Kekerasan, dan Perdamaian (Jakarta: Bidang Marturia, PGI, 2005). Di dalam buku tersebut tecermin pemikiran-pemikiran dari teolog Indonesia mengenai isu-isu seputar kekerasan, agama dan juga perdamaian.
} 
tur dan multikulturalisme. Dengan demikian, pandangan terhadap kondisi multikulturalisme dan juga multikultur ini pun dapat berdampak pada cara pandang kaum injili terhadap orang asing (the other).

Indikatif yang kedua. Bagian indikatif yang kedua ini berhubungan dengan cara pandang seorang injili pada orang asing (the other) yang ada di sekitarnya. Pada TCTC I.7.e, dinyatakan demikian:

We love our neighbours as ourselves. Jesus called his disciples to obey this commandment as the second greatest in the law, but then he radically deepened the demand (from the same chapter), love the foreigner as yourself' into 'love your enemies.' This love for our neighbours embraces people of other faiths, and extends to those who hate us, slander and persecute us, and even kill us. ${ }^{44}$

Konsep seorang asing (foreigner) mencakup konsep "yang lain" (the other) di dalamnya. Dampak dari pengakuan ini, sesama manusia (the foreigner) bagi seorang injili pun tercakup di dalamnya penganut agama yang lain (dalam konteks multikulturalisme dan multikultur). Tercakup juga di dalamnya penganut agama lain yang mempunyai sikap memusuhi ataupun mengayomi kaum injili. ${ }^{45}$ Dengan demikian, apabila pemikiran ini diaplikasikan ke dalam situasi multikultur dan multikulturalisme di Indonesia, sesama manusia bagi kaum injili adalah seluruh manusia-manusia Indonesia dengan keunikan suku, agama dan juga budaya.

Indikatif yang ketiga. Di dalam premis indikatif yang ketiga, terdapat pengakuan mengenai kebenaran yang hakiki atau sejati di dalam

44"The Cape Town Commitment: A Confession of Faith and A Call to Action," 75

${ }^{45}$ Menariknya, pada Manifesto Manila, terdapat pengakuan demikian: "In the past we have sometimes been guilty of adopting towards adherents of other faiths attitudes of ignorance, arrogance, disrespect and even hostility. We repent of this. We nevertheless are determined to bear a positive and uncompromising witness to the uniqueness of our Lord, in his life, death and resurrection, in all aspects of our evangelistic work including inter-faith dialogue" (lih. t.p., "The Manila Manifesto," artikel keempat). situasi multikultur. Terdapat pengakuan demikian pada TCTC II.A.2:

Cultural and religious plurality is a fact and Christians in Asia, for example, have lived with it for centuries. Different religions each affirm that theirs is the way of truth. Most will seek to respect competing truth claims of other faiths and live alongside them. However postmodern, relativist pluralism is different. Its ideology allows for no absolute or universal truth. While tolerating truth claims, it views them as no more than cultural constructs. (This position is logically selfdestroying for it affirms as a single absolute truth that there is no single absolute Truth.) Such pluralism asserts 'tolerance' as an ultimate value, but it can take oppressive forms in countries where secularism or aggressive atheism govern the public arena. ${ }^{46}$

Dengan pengakuan ini, tentunya problema ini mirip dengan konteks berteologi di Indonesia yang sudah penulis jelaskan di atas. Dengan demikian, penulis melihat bahwa ada dua dampak yang dapat dihasilkan dari pemahaman yang sudah penulis sadur di atas.

Pertama, terdapat perbedaan yang mendasar antara pluralitas (plurality) dari agama-agama dan juga ideologi pascamodern yang anti dengan kebenaran yang ultimat. ${ }^{47}$ Seperti penjelasan yang penulis utarakan pada indikatif yang pertama, seorang injili tidak anti dengan keragaman budaya yang ada di dunia ini (pluralitas). Namun, seorang injili perlu mewaspadai ideologi pascamodern yang memengaruhi zaman ini. Dengan demikian

46"The Cape Town Commitment: A Confession of Faith and A Call to Action," 68.

${ }^{47}$ Ideologi pascamodern yang disebutkan di sini lebih menyerupai konsep yang disebutkan oleh D. A. Carson yang bernama philosophical atau hermeneutical pluralism (lih. The Gagging of God: Christianity Confronts Pluralism, Fifteenth Edition [Zondervan, 2011], 13-22). Lih. juga konsep pluralitas yang diusulkan oleh Kobong dalam Agama dalam Dialog, 124-125. 
ada jenis toleransi yang tidak dapat diterima oleh kaum injili. ${ }^{48}$

Kedua, pengakuan di atas sebenarnya ingin kembali mengingatkan kaum injili untuk tetap berada di dalam jalur eksklusifnya. Pada prinsipnya, memamg setiap aliran kepercayaan akan mempunyai klaim kebenarannya yang eksklusif. ${ }^{49}$ Dengan demikian, tidak ada masalah apabila seorang injili meyakini bahwa keyakinannya adalah yang paling benar. ${ }^{50}$ Namun, tetap saja kebenaran ini tidak dapat dinyatakan di dalam cara-cara yang salah. Tidak hanya itu, dengan mengetahui kebenaran ini, seorang injili seharusnya

${ }^{48}$ Beberapa teolog Indonesia pun sudah mencoba untuk mengusulkan beberapa model bertoleransi untuk dilakukan di Indonesia di dalam model dialog antariman. Beberapa pandangan yang sudah ada misalkan saja sudah dikembangkan oleh J. B. Banawiratma (lih. "Bersama Saudara-saudari Beriman Lain," dalam Dialog: Kritik \& Identitas Agama, 3rd ed. [Yogyakarta: Interfidei, 2004], 15-35; "Mengembangkan Teologi Agama-agama," dalam Meretas Jalan Teologi Agama-agama di Indonesia, ed. Tim Balitbang PGI [Jakarta: Gunung Mulia, 1999]; "Christian Life in Religious Pluralism: Ecumenical Concerns in Interreligious Dialogue," CTC Bulletin V, no. 2 [December 1998]: 46-52). Banawiratma mengusulkan model pluralisme dialogal sebagai model bertoleransi dan juga model bagi seorang Kristen untuk hidup di Indonesia. Tidak hanya itu, model dialog antar-agama pun sudah diusulkan oleh Joas Adiprasetya (lih. "(Post-) Liberalisme dan Perjumpaan Antar Iman," Penuntun 5, no. 19 [2013]: 287-298; "Berteologi dalam Perjumpaan dengan Sang Lain," Jurnal Teologi Proklamasi 2, no. 1 [June 2002]: 287-298; Mencari Dasar Bersama [Jakarta: Gunung Mulia, 2002]). Adiprasetya mengusulkan model dialog pascaliberalistis-orthopraksis sebagai usulan model toleransi antar agama di Indonesia. Lihat juga beberapa model dialog yang disarankan oleh beberapa teolog Indonesia dalam Balitbang PGI, Agama dalam Dialog.

${ }^{49}$ Sebagaimana diutarakan juga oleh seorang teolog agama-agama yang ternama, Raimon Panikkar (lih. The Intra-Religious Dialogue, reprint. [Mahwah: Paulist, 1999], 5).

${ }^{50}$ Pada TCTC II.A.1, terdapat pengakuan demikian: "Jesus Christ is the truth of the universe. Because Jesus is truth, truth in Christ is (i) personal as well as propositional; (ii) universal as well as contextual; (iii) ultimate as well as present"("The Cape Town Commitment: A Confession of Faith and A Call to Action," 67). Schreiter menduga bahwa konsep yang melatarbelakangi dokumen ini sangatlah kental dengan konsep Injil Yohanes ("From the Lausanne Covenant to the Cape Town Commitment: A Theological Assesment," 90). Penulis sepaham dengan Schreiter, dengan demikian konsep kebenaran yang diungkapkan pada dokumen ini kemungkinan besar berhubungan dengan karya keselamatan Kristus yang eksklusif. dapat hidup dengan rendah hati, "rejecting the idolatry of power." 51

Imperatif yang pertama. Poin ini akan berbicara mengenai tindakan-tindakan yang seharusnya dilakukan oleh seorang injili yang didasari oleh kasih terhadap sesama, sesuai dengan indikatif yang pertama dan kedua. Pada TCTC I.7.b terdapat pernyataan demikian:

Such love for all peoples demands that we reject the evils of racism and ethnocentrism, and treat every ethnic and cultural group with dignity and respect, on the grounds of their value to God in creation and redemption..$^{52}$

We emphatically reject the way of violence in the spread of the gospel, and renounce the temptation to retaliate with revenge against those who do us wrong. Such disobedience is incompatible with the example and teaching of Christ and the New Testament. ${ }^{53}$

Di dalam situasi multikultur dengan kekerabatan yang kuat di Indonesia, rasisme dan primordialisme merupakan ancaman laten. Dengan demikian, lewat pembahasan dokumen ini, seorang injili perlu celik terhadap ancaman laten ini sebagaimana yang diutarakan di dalam pernyataan-pernyataan di atas.

Wujud nyata dari mengasihi sesama (the foreigner) di sekitar kita pun mewujud di dalam pemberitaan Injil via tindakan nirkekerasan. Di dalam situasi multikultur dengan kekerabatan yang kuat di Indonesia, rasisme dan primordialisme dapat memicu konflik yang mewujud di dalam kekerasan. ${ }^{54}$ Karena itu, seorang injili tidak bisa membalas kejahatan dengan kejahatan, sebagaimana ajaran Yesus. Tentunya, sikap mengasihi sesama ini pun harus dibarengi dengan pewartaan kebenaran di dalam situasi yang multikultur ini. Pewartaan kebenaran ini dapat dilakukan dengan

${ }^{51}$ Bagian ini secara khusus dicatat dalam TCTC II.E.3 (lih. "The Cape Town Commitment: A Confession of Faith and A Call to Action," 76).

${ }^{52}$ Ibid., 64.

${ }^{53}$ Ibid., 65.

${ }^{54}$ Sebagai bagian yang mendukung tindakan ini, terdapat konteks seorang injili dapat menjadi pembawa damai pada TCTC II.B.2.A (lih. ibid., 70). 
hidup benar dan juga mewartakan kabar mengenai Yesus Kristus yang tersalib. Pewartaan demikian (menghidupi kebenaran) pun merupakan wujud dari toleransi yang seharusnya diusung oleh kaum injili.

Imperatif yang kedua. Perintah yang kedua berhubungan dengan indikatif yang ketiga, yaitu mengenai menghidupi kebenaran. Pada imperatif yang ketiga ini, dasar dari perintah ini adalah agar seorang Kristen menjadi murid-murid Kristus. Murid-murid Kristus "are called to be people of truth." 55 TCTC II.A.1 menyatakan demikian:

We must live the truth. To live the truth is to be the face of Jesus, through whom the glory of the gospel is revealed to blinded minds. People will see truth in the faces of those who live their lives for Jesus, in faithfulness and Love. ${ }^{56}$

Di tengah-tengah dunia yang berdosa dan telah jatuh, seorang injili dipanggil untuk melakonkan kebenaran di dalam kehidupannya. Karena itu, minimal lewat poin yang pertama, terdapat tiga dampak yang dapat direnungkan lebih jauh.

Pertama, konsistensi untuk mengikuti jalan kebenaran. Tentunya, sangatlah menyedihkan apabila kehadiran seorang injili di dalam ruang publik justru tidak menunjukkan perilaku yang sesuai dengan pikiran Kristus, justru orang-orang di sekitar seorang Kristen malah melihat perilaku yang lebih parah. ${ }^{57}$ Kedua, lewat pengakuan ini, minimal seorang injili harus masuk ke dalam ruang publik, agar "the glory of the gospel is revealed to blinded minds." 58 Tentunya, agar kebenaran itu dapat dilihat pada ruang publik, seorang injili tidak dapat membentuk komunitas ghetto. ${ }^{59}$

\footnotetext{
${ }^{55}$ Ibid., 67.

${ }^{56}$ Ibid., 67-68.

${ }^{57}$ Pembahasan yang lebih mendetail di dalam bagian ini dapat dilihat pada TCTC II.A-II.E.

${ }^{58}$ Lihat juga pembahasan ini lebih jauh lagi pada TCTC II.A.3-II.A.7.

${ }^{59}$ Untuk pembahasan mengenai ghetto, Yewangoe sudah mencoba untuk membahas mengenai problema ini dalam Tidak Ada Ghetto (Jakarta: Gunung Mulia, 2009).
}

Ketiga, seorang injili perlu konsisten untuk menjadi berbeda, di dalam arti menghidupi jalan panggilan Tuhan sebagai ciptaan yang baru. ${ }^{60}$ Dengan demikian, jalan panggilan dari seorang Kristen bukanlah berbeda dalam arti memisahkan diri dengan dunia (ghetto), tetapi di dalam mempraktikkan jalan kebenaran yang sudah Tuhan tunjukkan lewat firman-Nya.

Imperatifyang ketiga. Perintah yang dibangun dari imperatif ini merupakan sambungan dari imperatif yang kedua sebagai respons atas indikatif ketiga. Pada TCTC II.A.1 terdapat pengakuan demikian: "We must proclaim the truth. Spoken proclamation of the truth of the gospel remains paramount in our mission. This cannot be separated from living out the truth." 61 Sebagai bagian dari menghidupi kebenaran Kristen, "Works and words must go together."62 Dasar dari kebenaran ini pun adalah setiap seorang Kristen adalah murid-murid Kristus. Sebagai murid dari Kristus, kebenaran mengenai Kristus perlu disampaikan juga secara oral. ${ }^{63}$ Tidak hanya itu, tujuan dari menyatakan kebenaran ini pun berhubungan

${ }^{60}$ Lih. TCTC II.E.1 untuk penjelasan yang lebih lengkap (lih. "The Cape Town Commitment: A Confession of Faith and A Call to Action," 75).

${ }^{61}$ Ibid., 67-68.

${ }^{62}$ Ibid., 68.

${ }^{63}$ Memang ada pula suatu masukan pada bagian ini yang menyatakan bahwa penginjilan yang dimiliki di dalam dokumen ini masih terikat pada penginjilan oral (lih. Padilla, "The Future of the Lausanne Movement," 87). Maksud dari Padilla, misi Allah tidak dapat direduksi di dalam penginjilan oral semata. Penulis sepaham dengan Padilla. Namun, walau tidak dibahas secara langsung, penulis melihat bahwa sudah terdapat maksud yang cukup eksplisit di dalam dokumen ini untuk menyatukan tanggung jawab sosial dengan penginjilan. Ada kemungkinan bahwa tidak dibahasnya dua isu penting ini dikarenakan pada Manifesto Manila, dua isu ini sudah disandingkan. Karena itu, sebagai kelanjutan dari dokumen ini, hubungan dari penginjilan dan tanggung jawab sosial tidak dimasukkan lagi ke dalam dokumen dan menjadi semacam asumsi. 
dengan pengabaran karya keselamatan Kristus pada seluruh dunia. ${ }^{64}$

Dasar dari pengabaran Injil pada seluruh dunia adalah kasih dari Allah itu sendiri pada seluruh bangsa. Pada TCTC I.7.b, terdapat pengakuan demikian:

Such love [untuk dunia dan budaya] also demands that we seek to make the gospel known among every people and culture everywhere. No nation, Jew or Gentile, is exempt from the scope of the Great Commission. Evangelism is the outflow of hearts that are filled with the love of God for those who do not yet know him. ${ }^{65}$

Apabila konsep ini mau diaplikasikan pada kondisi multikultur di Indonesia, maka pengabaran Injil Kristus pun perlu dikabarkan pada seluruh suku, kaum dan bahasa. Penginjilan, "the outflow of hearts that filled with the love of God," merupakan bagian dari kehidupan yang benar, kehidupan sebagai murid Kristus. ${ }^{66}$ Dengan demikian, seorang injili perlu juga mencari wujud teologi yang kontekstual di Indonesia, agar Injil dapat masuk dan relevan bagi kondisi sosial di Indonesia. ${ }^{67}$

${ }^{64}$ Pada dokumen TCTC I.10, terdapat pengakuan demikian: "God commands us to make known to all nations the truth of God's revelation and the gospel of God's saving grace through Jesus Christ, calling all people to repentance, faith, baptis and obedient discipleship" (lih. "The Cape Town Commitment: A Confession of Faith and A Call to Action," 67-68).

${ }^{65}$ Ibid., 64-65; penambahan oleh penulis.

${ }^{66}$ Definisi penginjilan sendiri sudah memiliki banyak pengertian. Karena dokumen TCTC merupakan kelanjutan dari dua dokumen yang sebelumnya, definisi dari penginjilan pun ada pada dokumen The Lausanne Covenant, artikel keempat (t.p., "The Lausanne Covenant").

${ }^{67}$ Ira D. Mangililo mencoba menjawab isu teologi yang kontekstual ini di dalam kacamata teologi feminis (lih. "Teologi Feminis di Indonesia sebagai Teologi di Ruang Ketiga," dalam Dari Disabilitas ke Penebusan, ed. Ronald Arulangi et al. [Jakarta: Gunung Mulia, 2016]). Salah satu usulan menarik yang diutarakan oleh Mangililo adalah suatu usaha untuk melampaui teologi feminis yang ada di Barat dan mengontekskannya di Indonesia. Salah satu tulisan yang baik juga mengenai kontekstualisasi dapat dilihat pada Fially Fallderama, "Ajek dan Lentur: Pengkajian Ulang Atas Teologi Kontekstual," dalam Dari Disabilitas ke Penebusan, ed. Ronald Arulangi et al. (Jakarta: Gunung Mulia, 2016), 217-232. Lih. juga Gerith Singgih, Dari Israel Ke Asia, revisi. (Jakarta: Gunung Mulia, 2012).

\section{Apa yang Harus Komitmen Cape Town Katakan pada Problema Kemiskinan dan Ketimpangan di Indonesia}

Indikatif yang keempat. Pada indikatif ini, Komitmen Cape Town memberikan pandangan mengenai kemiskinan di dalam sudut pandang Alkitabiah. Pada TCTC I.7.C, terdapat pemahaman demikian:

We love the world's poor and suffering. The Bible tells us that the Lord is loving toward all he has made, upholds the cause of the oppressed, loves the foreigner, feeds the hungry, sustains the fatherless and widow. The Bible also shows that God wills to do these things through human beings committed to such action. God holds responsible especially those who are appointed to political or judicial leadership in society, but all God's people are commanded-by the law and prophets, Psalms and Wisdom, Jesus and Paul, James and John-to reflect the love and justice of God in practical love and justice for the needy. ${ }^{68}$

Pengakuan ini sangatlah penting mengingat kaum injili sering kali luput untuk membahas tanggung jawab sosial (social concern) ${ }^{69}$ Bagi penulis, minimal terdapat dua dampak dari pengakuan ini terhadap paradigma seorang injili terhadap kemiskinan dan juga ketimpangan. Pertama, kesaksian dari dokumen ini mengingatkan seorang injili bahwa orangorang yang miskin juga diperhatikan oleh Tuhan. $^{70}$ Sebagai dampaknya, seorang injili pun perlu memperhatikan nasib dari orang-

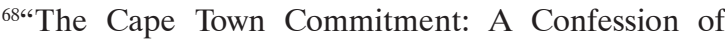
Faith and A Call to Action," 64-65.

${ }^{69}$ Penulis meminjam istilah tanggung jawab sosial (social concern) ini dari John Stott. Untuk pembahasan mengenai problema ini, lih. Issues Facing Christian Today, 4th ed. (Grand Rapids: Zondervan, 2011), 23-24.

${ }^{70}$ Pada bagian yang sama, terdapat pengakuan demikian: "We confess with shame that on this matter we fail to share God's passion, fail to embody God's love, fail to reflect God's character and fail to do God's will. We give ourselves afresh to the promotion of justice, including solidarity and advocacy on behalf of the marginalized and oppressed" (lih. "The Cape Town Commitment: A Confession of Faith and A Call to Action," 65). Tentunya, pengakuan ini menunjukkan bahwa ada semacam perubahan dari pandangan kaum injili mengenai tanggung jawab sosial dan juga penginjilan (lih. t.p., "The Manila Manifesto," artikel keempat). 
orang miskin, sebagaimana Tuhan memperhatikan mereka. ${ }^{71}$ Kedua, seorang injili pun perlu menyadari bahwa keadilan sosial dan tanggung jawab sosial pun ada di dalam kisahkisah yang dipaparkan oleh Injil ataupun surat-surat Paulus. Dengan demikian, penginjilan dan tanggung jawab sosial tidak dapat dipisahkan di dalam kehidupan seorang injili.

Indikatif yang kelima. Pengakuan terhadap dosa non-spiritual. Pada TCTC 1.7.C, terdapat pengakuan bahwa

We recognize such struggle against evil as a dimension of spiritual warfare that can only be waged through the victory of the cross and resurrection, in the power of the Holy Spirit, and with constant prayer. ${ }^{72}$

Lewat pengakuan ini, secara tersirat terdapat pengakuan terhadap dosa non-spiritual yang secara nyata terlihat di dalam budaya manusia. Dosa tidak hanya mencemari diri manusia, namun juga budaya. Sebagai dampaknya, penindasan menjadi wujud nyata dari dosa ini. Dengan demikian, seorang injili seharusnya berada di garda terdepan untuk melawan berbagai penindasan. Hal yang menarik, perjuangan melawan dosa ini pun dilakukan dengan hal yang berdoa dan didasarkan pada kekuatan dari salib dan kebangkitanNya. Dengan demikian, seharusnya tidak ada pemisahan spiritual-duniawi di dalam kacamata seorang injili, terutama di dalam perdebatan aksi sosial dan juga penginjilan. ${ }^{73}$

\footnotetext{
${ }^{71}$ Lih. juga Theodorus B. Sibarani, "Berteologi dalam Pembangunan Sosial di Indonesia," dalam Dari Disabilitas ke Penebusan, ed. Ronald Arulangi et al. (Jakarta: Gunung Mulia, 2016). Sibarani menyatakan bahwa pembangunan sosial dan Pancasila sebagai dasarnya. Memang, bagi penulis, seorang injili perlu untuk memikirkan alternatif yang lain. Namun, tulisan dari Sibarani dapat menjadi masukan yang baik dari pemikiran kaum injili di Indonesia.

72" The Cape Town Commitment: A Confession of Faith and A Call to Action," 65.

${ }^{73}$ Padilla memberikan pendapat bahwa di dalam dokumen ini pun terdapat cacat, yaitu terdapat pemisahan di dalam konsep sakral dan sekuler (lih. "The Future of the Lausanne Movement," 87). Sekali lagi, penulis sepaham dengan Padilla bahwa konsep ini tidak secara langsung dibahas pada dokumen ini secara mendalam. Namun, penulis melihat bahwa pemisahan ini tidak sepenuhnya benar. Penulis melihat bahwa secara tersirat, sudah mulai ada kepedulian untuk menjawab pemisahan ini sebagaimana yang sudah penulis utarakan pada poin di atas.
}

Perjuangan spiritual juga harus dinyatakan di dalam dunia nyata, yaitu melawan opresi dan kemiskinan.

Imperatif yang keempat. Rasa cinta kasih kepada Tuhan dapat dijalankan di dalam aksi yang berujung kepada pendirian keadilan di dalam dunia. Pada TCTC I.7.C, terdapat pengakuan demikian:

Such love for the poor demands that we not only love mercy and deeds of compassion, but also that we do justice through exposing and opposing all that oppresses and exploits the poor. 'We must not be afraid to denounce evil and injustice wherever they exist ${ }^{74}$

Penulis melihat bahwa tindakan kasih yang dinyatakan dalam keadilan ini tidak dapat dilepaskan dari imperatif kedua dan ketiga. Dengan demikian, lewat pengakuan ini, minimal tidak ada pemisahan antara penginjilan dan juga aksi sosial. ${ }^{75}$ Keduanya merupakan bagian dari misi Allah. ${ }^{76}$ Tidak hanya itu, dengan menunjukkan aksi ini, justru seorang injili justru sedang menjadi seorang saksi Kristus atau martir kebenaran yang terus mewartakan Injil kerajaan Allah di dalam dunia. ${ }^{77}$

Imperatif yang kelima. Lokus dari pembahasan ini adalah aksi nyata yang dapat dilakukan seorang injili di dalam memerangi kemiskinan yang sistemik. TCTC II.B.3.b menyatakan demikian:

74“"The Cape Town Commitment: A Confession of Faith and A Call to Action," 65.

${ }^{75}$ Salah satu pertemuan yang penting di dalam membahas dikotomi ini dapat dilihat pada Chris Sugden dan David Bosch, "From Partnership to Marriage: Consultation on the Relationship between Evangelism and Social Responsibility (CRESR)," Themelios 8, no. 2 (1983): 26-27. Hal yang menarik, pada dokumen Manifesto Manila, tidak ada pemisahan di dalam pembahasan penginjilan dan juga tanggung jawab sosial (lih. t.p., "The Manila Manifesto," artikel keempat). Karena itu, dengan pengakuan ini, kaum injili dapat lebih bebas lagi di dalam merumuskan hubungan tanggung jawab sosial dan juga penginjilan.

${ }^{76}$ Lih. TCTC I.5.c (lih. "The Cape Town Commitment: A Confession of Faith and A Call to Action," 63).

${ }^{77}$ Lih. TCTC II.C.2 (lih. ibid., 72). Penulis sendiri sudah mencoba untuk membahas ide ini di dalam "Wahai Pengikut Kristus, Mainkanlah Drama yang Mentransformasikan Itu!," Indonesian Journal of Theology 3, no. 2 (December 2015): 185-205. 
We embrace the witness of the whole Bible, as it shows us God's desire both for systemic economic justice and for personal compassion, respect and generosity towards the poor and needy. ${ }^{78}$

Dengan pengakuan ini, terdapat tiga level pengaruh yang menjadi sasaran dari kaum injili untuk mendirikan suatu keadilan ekonomi yang tersistem (systemic economic justice) dan juga mengaplikasikan hasrat untuk mewujudkan keadilan tersebut (personal compassion). ${ }^{79}$ Pada level yang pertama adalah tingkatan individu. Seorang injili perlu bergerak masuk ke dalam dunia akademis, masuk ke dalam dunia ekonomi, perbankan, sosiologi, dsb. ${ }^{80}$ Di dalam bidang-bidang tersebut, orang-orang injili dapat menjadi seorang akademisi ataupun praktisi yang handal dan profesional.

Pada level ini pula seorang injili justru ditantang untuk terus melawan keserakahan yang menjadi inti utama dari sifat penindas ini. ${ }^{81}$ Karena itu, dengan ditekannya keserakahan, kehidupan yang sederhana seharusnya menjadi bagian dari kehidupan seorang injili. Tidak hanya itu, seorang injili pun dapat menjadi penyalur berkat Allah pada orang-orang di sekitarnya. Dengan demikian, kesadaran akan misi ilahi ini dapat dilanjutkan ke dalam tingkat berikutnya, yaitu tingkatan golongan.

Gereja sebagai tubuh Kristus perlu terus mengimplementasikan tindakan anti keserakahan. Dengan demikian, hemat penulis, gereja pun seharusnya dapat lebih memperhatikan lingkungan di sekitarnya dan mulai memperhatikan prinsip kesederhanaan.

${ }^{78}$ The Cape Town Commitment: A Confession of Faith and A Call to Action," 70.

${ }^{79} \mathrm{PGI}$ sendiri sudah membukukan beberapa buku yang sangat baik mengenai agama dan juga problema kemiskinan di Indonesia. Beberapa buku yang dapat dijadikan referensi adalah A. A. Yewangoe, "Keprihatinan Dan Harapan Gereja Terhadap Masalah Kemiskinan Di Indonesia." Tidak hanya itu, lih. juga Ferry Y. Mamahit, "Globalisasi, Gereja Injili dan Transformasi Sosial," Veritas 6, no. 2 (Oktober 2005): 253-375.

${ }^{80}$ Lih. TCTC II.F.4 (lih. "The Cape Town Commitment: A Confession of Faith and A Call to Action," 77).

${ }^{81}$ Lih. TCTC II.E.5 (lih. ibid.).
Lebih jauh lagi, gereja juga perlu menjadi suara kenabian yang dapat memberikan suara kebenaran terhadap ilah-ilah zaman. ${ }^{82}$ Pada tingkatan yang lebih tinggi lagi, seorang injili juga perlu memikirkan kerja sama antara institusi. Inilah tingkatan yang kedua.

Pada tingkatan ini, gereja-gereja injili perlu menyatukan visi untuk menggarap misi ilahi ini di dalam kerja sama antargereja. ${ }^{83}$ Dengan demikian, ladang Allah yang begitu luas ini dapat secara efektif digarap bersama-sama. Karena kemiskinan sistemik ini tidak dapat dilawan apabila tidak ada suatu gerakan bersama. Karena itu, kolaborasi ini pun seharusnya terjadi antara institusi (universitas, LSM dan organisasi lainnya) dan gereja. ${ }^{84}$ Dengan demikian, hemat penulis, gerakan ini dapat menjadi suatu perlawanan terhadap kemiskinan dan juga ketimpangan yang melanda Indonesia.

Penulis melihat dengan melaksanakan tiga tingkatan ini, kaum injili dapat menjalankan perintah-Nya untuk menjadi saksi dan juga menjalankan misi Allah dengan terintegrasi di dalam berbagai bidang kehidupan.

\section{Kesimpulan}

Dengan demikian, apakah yang (dokumen) Cape Town perlu katakan pada kaum injili di Indonesia? Penulis akan memberikan tiga jawaban. Jawaban yang pertama, berada dalam bentuk lima indikatif dan lima imperatif. Demikianlah lima indikatif dan juga lima imperatif tersebut:

${ }^{82}$ Lih. TCTC II.E.3 (lih. ibid., 76). Kartika Diredja sudah memberikan idenya mengenai partisipasi orangorang Tionghoa pada ruang publik (lih. "YESUS, SANG ORANG ASING: Alternatif Kristologi bagi Orang Indonesia-Tionghoa-Kristen," Indonesian Journal of Theology 2, no. 2 [Desember 2014]: 119-135). Diredja menyatakan bahwa status orang asing yang sering disematkan pada kaum Tionghoa seharusnya membuat seorang Tionghoa dapat berpartisipasi aktif di dalam menjalankan misi ilahi di dunia ini.

${ }^{83}$ Lih. TCTC II.F.1 (lih. "The Cape Town Commitment: A Confession of Faith and A Call to Action," 77).

${ }^{84}$ Lih. TCTC II.F.2 (lih. ibid., 77-78). 
Indikatif pertama Kondisi multikultur dan multikulturalisme yang ada di Indonesia begitu indah walau tercemar dosa.

Indikatif kedua Sesama manusia di dalam konteks multikultur dan multikulturalisme di Indonesia adalah semua manusia Indonesia dengan segala keunikannya.

Indikatif ketiga Di tengah-tengah kondisi multikultur dan multikulturalisme, Yesus Kristus adalah kebenaran Allah.

Indikatif keempat Allah, lewat firman-Nya, membahas dan peduli mengenai problema kemiskinan dan kesenjangan.

Indikatif kelima Kemiskinan pun merupakan produk dari dosa yang dinyatakan lewat budaya.

Imperatif pertama Kasihilah sesamamu manusia termasuk di dalamnya orang-orang yang berbeda suku, denominasi, ataupun ras di dalam budaya multikultur dan multikulturalisme di Indonesia!

Imperatif kedua Berbahagialah seorang injili yang menghidupi kebenaran dan terus melakukannya di dalam kehidupan kesehariannya!

Imperatif ketiga Berbahagialah seorang injili yang terus mewartakan kebenaran Injil Kristus di mana pun dia berada!

Imperatif keempat Berbahagialah seorang injili yang tidak memisahkan tanggung jawab sosial dengan penginjilan!

Imperatif kelima Jadikan kami, kaum injili, satu!

Penulis melihat bahwa jawaban yang kedua, berhubungan dengan teologi injili yang holistik dan kontekstual. Bagi penulis, dokumen Komitmen Cape Town menyiratkan suatu kebutuhan ini. Dampaknya, seorang teolog injili, dengan atau tanpa menggunakan dokumen ini, perlu memikirkan suatu teologi injili yang kontekstual dan integratif di dalam konteks keindonesiaan. Dengan demikian, seorang injili juga perlu berdialog dengan teologteolog lainnya.
Terakhir, dokumen Komitmen Cape Town juga berbicara mengenai aksi seorang injili di ruang publik. Seorang injili tidak hanya perlu merumuskan teologi yang kontekstual dan holistik, namun juga menghidupi teologi injili tersebut. Sehingga, di dalam ruang publik, dapatlah nyata karya dari kaum injili. Dengan demikian, inilah yang dapat penulis simpulkan mengenai apakah yang (dokumen) Cape Town dapat katakan pada (kaum injili) di Indonesia. 


\section{Daftar Kepustakaan}

Adiprasetya, Joas. "Berteologi dalam Perjumpaan dengan Sang Lain.” Jurnal Teologi Proklamasi 2, no. 1 (June 2002): 287-298. . Mencari Dasar Bersama. Jakarta: Gunung Mulia, 2002. 298. . “(Post-) Liberalisme dan Perjumpaan Antar Iman.” Penuntun 5, no. 19 (2013): 287-

Aritonang, Jan S. Berbagai Aliran di Dalam dan di Sekitar Gereja. 5th ed. Jakarta: Gunung Mulia, 2010.

Balitbang PGI, ed. Agama dalam Dialog. Jakarta: Gunung Mulia, 1999.

Banawiratma, J. B. "Bersama Saudara-saudari Beriman Lain.” Dalam Dialog: Kritik \& Identitas Agama, 15-35. 3rd ed. Yogyakarta: Interfidei, 2004.

. "Christian Life in Religious Pluralism: Ecumenical Concerns in Interreligious Dialogue.” CTC Bulletin V, no. 2 (December 1998): 46-52.

. "Mengembangkan Teologi Agama-agama." Dalam Meretas Jalan Teologi AgamaAgama di Indonesia, diedit oleh Tim Balitbang PGI. Jakarta: Gunung Mulia, 1999.

Bidang Marturia, ed. Agama-agama, Kekerasan, dan Perdamaian. Jakarta: Bidang Marturia, PGI, 2005.

Bowen, John R. "Return to Sender: A Muslim Discourse of Sorcery in a Relatively Egalitarian Society, the Gayo of Northern Sumatra." Dalam Understanding Witchcraft and Sorcery in Southeast Asia, diedit oleh C. W. Watson dan R. F. Ellen, 179-190. Hawaii: University of Hawaii Press, 1993.

BPS. “Berita Statistik September 2015.” Diakses 20 Mei 2016. https://www.bps.go.id/index.php/ brs/1277.

Kewarganegaraan, Suku Bangsa, Agama, dan Bahasa Sehari-Hari Penduduk Indonesia. t. k.: BPS, 2010. Diakses 25 Oktober 2015. http://www.bps.go.id/website/pdf_publikasi/watermark\%20_Kewarganegaraan,\%20Suku\%20Bangsa,\%20Agama\%20dan\%20 Bahasa_281211.pdf. kator/22.

. “Koefisien GINI.” Diakses 20 Mei 2016. https://sirusa.bps.go.id/sirusa/index.php/indi-

. Laporan Bulanan Data Statistik Agustus 2016. Diedit oleh Subdirektorat Publikasi dan Kompilasi Statistik. t. k.: BPS, 2016. Diakses 30 Agustus 2016. https://www.bps.go.id/website/ pdf_publikasi/Laporan-Bulanan-Data-Sosial-Ekonomi-Agustus-2016.pdf. view/id/23.

. "Perhitungan Garis Kemiskinan.” Diakses 29 Juli 2016. https://www.bps.go.id/Subjek/

. "Persentase Penduduk Miskin Maret 2016 Mencapai 10,86 Persen.” Diakses 29 Juli 2016. https://www.bps.go.id/Brs/view/id/1229.

Brown, Lindsay. "We Have a Gospel to Proclaim." Dalam The Lausanne Legacy, diedit oleh J. E. M. Cameron. Peabody: Hendrickson, 2016.

Cameron, J. E. M. ed. The Lausanne Legacy. Peabody: Hendrickson, 2016. 
Carson, D. A. The Gagging of God: Christianity Confronts Pluralism. Fifteenth Edition. Zondervan, 2011.

. "Revisi Atas Garis Kemiskinan.” Kompas, April 11, 2014.

Cunningham, Clarke E. "Indonesia." Diedit oleh Carol R. Ember dan Melvin Ember. Countries and Their Cultures. New York: Macmillan Reference USA, 2001. Gale Virtual Reference Library.

Diredja, Kartika. "YESUS, SANG ORANG ASING: Alternatif Kristologi bagi Orang Indonesia-Tionghoa-Kristen.” Indonesian Journal of Theology 2, no. 2 (Desember 2014): 119-135.

Ellen, Roy. "Anger, Anxiety, and Sorcery: An Analysis of Some Nuaulu Case Material from Seram, Eastern Indonesia." Dalam Understanding Witchcraft and Sorcery in Southeast Asia, diedit oleh C. W. Watson dan R. F. Ellen, 81-97. Hawaii: University of Hawaii Press, 1993.

Fallderama, Fially. "Ajek dan Lentur: Pengkajian Ulang Atas Teologi Kontekstual.” Dalam Dari Disabilitas Ke Penebusan, diedit oleh Ronald Arulangi, Hans Abdiel Harmakaputra, Nindyo Sasongko, dan Abraham Silo Wilar, 217-232. Jakarta: Gunung Mulia, 2016.

Firdausy, Carunia Mulya. “Garis Kemiskinan Perlu Dinaikkan.” Kompas, October 17, 2014. Diakses 17 April 2016. http://www.dikti.go.id/garis-kemiskinan-perlu-dinaikkan/.

Ford, Leighton. "Foreword." Dalam The Lausanne Legacy, diedit oleh J. E. M. Cameron, vixxxii. Peabody: Hendrickson, 2016.

Forth, Gregory. "Social and Symbolic Aspect of the Witch among the Nage of Eastern Indonesia." Dalam Understanding Witchcraft and Sorcery in Southeast Asia, diedit oleh C. W. Watson dan R. F. Ellen, 99-122. Hawaii: University of Hawaii Press, 1993.

Hunt, Robert A. "The History of the Lausanne Movement, 1974-2010." International Bulletin of Missionary Research 35, no. 2 (April 2011): 81-84.

Lubis, Mochtar. Manusia Indonesia. Jakarta: Idayu, 1974.

McGrath, Alister. Evangelicalism and The Future of Christianity. Downer Grove: Inter Varsity Press, 1995.

Mamahit, Ferry Y. "Globalisasi, Gereja Injili dan Transformasi Sosial." Veritas 6, no. 2 (Oktober 2005): 253-375.

Mangililo, Ira D. "Teologi Feminis di Indonesia sebagai Teologi di Ruang Ketiga.” Dalam Dari Disabilitas ke Penebusan, diedit oleh Ronald Arulangi, Hans Abdiel Harmakaputra, Nindyo Sasongko, dan Abraham Silo Wilar. Jakarta: Gunung Mulia, 2016.

Neff, David. "Love Language.” Christianity Today, Desember 2010.

Netland, Harold, dan Gerald R. McDermott. A Trinitarian Theology of Religions: An Evangelical Proposal. Oxford: Oxford University Press, 2014.

Nitibaskara, Ronny. "Observation on the Practice of Sorcery in Java." Dalam Understanding Witchcraft and Sorcery in Southeast Asia, diedit oleh C. W. Watson dan R. F. Ellen, 123-133. Hawaii: University of Hawaii Press, 1993.

Noll, Mark A. "Ecumenical Realities and Evangelical Theology." Dalam Renewing the Evangelical Mission, diedit oleh Richard Lints. Grand Rapids: Eerdmans, 2013.

. Turning Points: Decisive Moments in the History of Christianity. Third Edition. Grand Rapids: Baker Academic, 2012. 
Packer, J. I., dan Thomas C. Oden. Satu Iman. Diedit oleh Yessy dan Lautan Asima Siregar. Jakarta: Gunung Mulia, 2011.

Padilla, C. René. "The Future of the Lausanne Movement." International Bulletin of Missionary Research 35, no. 2 (April 2011): 86-87.

Panikkar, Raimon. The Intra-Religious Dialogue. Reprint. Marwah: Paulist, 1999.

Sarapung, Elga, Noegroho Agoeng, dan Alfred B. Jogoena, eds. Dialog: Kritik \& Identitas. 3rd ed. Yogyakarta: Interfidei, 2004.

Schiller, Anne. "An 'Old' Religion in 'New Order' Indonesia: Notes on Ethnicity and Religious Affiliation." Sociology of Religion 57, no. 4 (Winter 1996): 409-417.

Schreiter, Robert J. "From the Lausanne Covenant to the Cape Town Commitment: A Theological Assesment.” International Bulletin of Missionary Research 35, no. 2 (April 2011): 89-91.

Sibarani, Theodorus B. "Berteologi dalam Pembangunan Sosial di Indonesia." Dalam Dari Disabilitas ke Penebusan, diedit oleh Ronald Arulangi, Hans Abdiel Harmakaputra, Nindyo Sasongko, dan Abraham Silo Wilar. Jakarta: Gunung Mulia, 2016.

Singgih, Gerith. Dari Israel Ke Asia. Revisi. Jakarta: Gunung Mulia, 2012.

Stott, John R. W. Issues Facing Christian Today. 4th ed. Grand Rapids: Zondervan, 2011.

Sugden, Chris, dan David Bosch. "From Partnership to Marriage: Consultation on the Relationship between Evangelism and Social Responsibility (CRESR)." Themelios 8, no. 2 (1983).

Susabda, Yakub B. Kaum Injili. 2nd ed. Malang: Gandum Mas, 1997.

t.p. "About the Movement." Diakses 31 Agustus 2016. https:/www.lausanne.org/about-themovement.

. "Pengentasan Kemiskinan Di Indonesia." Diakses 14 September 2015. http://www. worldbank.org/in/country/indonesia/brief/reducing-extreme-poverty-in-indonesia.

. "The Lausanne Covenant." Diakses 23 September 2016. https://www.lausanne.org/ content/covenant/lausanne-covenant.

. "Butir-Butir Pancasila.” Diakses 22 Maret 2016. http://bphn.go.id/data/documents/ butir-butir_pancasila_1.doc.

. “Indonesia Rising Divide.” Diakses 13 Mei 2016. http://www.worldbank.org/en/news/ feature/2015/12/08/ indonesia-rising-divide.

. "Indonesia: Rising Inequality Risks Long-Term Growth Slowdown." Diakses 2 September 2016. http://www.worldbank.org/en/news/press-release/2015/12/08/rising-inequalityrisks-long-term-growth-slowdown.

. “The Manila Manifesto.” Diakses 8 September 2016. http://www.lausanne.org/content/manifesto/the-manila-manifesto.

. “Undang-Undang Republik Indonesia No. 1 Tahun 1974 Tentang Perkawinan.” Diakses 14 Maret 2016. http://www.kemenag.go.id/file/dokumen/UUPerkawinan.pdf.

Vanhoozer, Kevin J. First Theology: God, Scripture, and Hermeneutics. Downers Grove: InterVarsity, 2002.

Yewangoe, A. A. Tidak Ada Ghetto. Jakarta: Gunung Mulia, 2009. 
. "Keprihatinan dan Harapan Gereja terhadap Masalah Kemiskinan di Indonesia." Dalam Gerakan Oikumene: Tegar Mekar di Bumi Pancasila. 4th ed. Jakarta: Gunung Mulia, 2012.

Yosia, Adrianus. "Let the Indonesian Hear His Voice.” Consilium 13 (July 2015): 117-131.

."Wahai Pengikut Kristus, Mainkanlah Drama yang Mentransformasikan Itu!" Indonesian Journal of Theology 3, no. 2 (December 2015): 185-205.

“Kesenjangan Jadi Tantangan Besar.” Kompas, June 2, 2016.

"The Cape Town Commitment: A Confession of Faith and A Call to Action." International Bulletin of Missionary Research 35, no. 2 (April 2011): 59-80.

"WEA Joins Lausanne Movement in Celebrating 40th Anniversary of Lausanne Congress and Lausanne Covenant.” Diakses 31 Agustus 2016. http://www.worldea.org/news/4383/weajoins-lausanne-movement-in-celebrating-40th-anniversary-of-lausanne-congress-and-lausanne-covenant. 